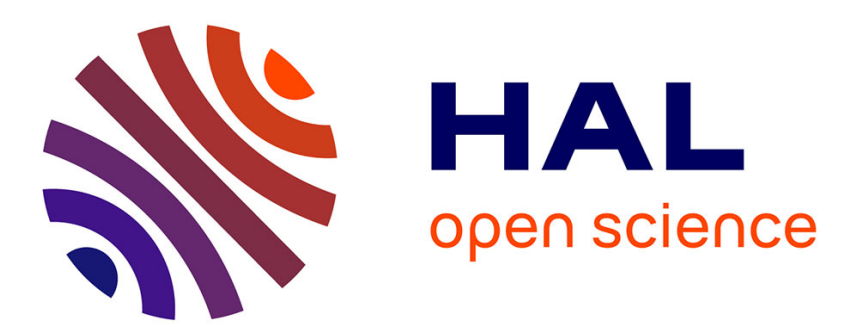

\title{
Fused Glycoluril-Tetrathiafulvalene Molecular Clips as Receptors for Neutral Electron Acceptor Guests
}

\author{
Yoann Cotelle, Magali Allain, Stéphanie Legoupy, Piétrick Hudhomme
}

\section{To cite this version:}

Yoann Cotelle, Magali Allain, Stéphanie Legoupy, Piétrick Hudhomme. Fused GlycolurilTetrathiafulvalene Molecular Clips as Receptors for Neutral Electron Acceptor Guests. Organic Letters, 2014, 16 (10), pp.2590-2593. 10.1021/ol500458e . hal-01301845

\section{HAL Id: hal-01301845 \\ https://hal.science/hal-01301845}

Submitted on 13 Apr 2016

HAL is a multi-disciplinary open access archive for the deposit and dissemination of scientific research documents, whether they are published or not. The documents may come from teaching and research institutions in France or abroad, or from public or private research centers.
L'archive ouverte pluridisciplinaire HAL, est destinée au dépôt et à la diffusion de documents scientifiques de niveau recherche, publiés ou non, émanant des établissements d'enseignement et de recherche français ou étrangers, des laboratoires publics ou privés. 


\title{
Fused Glycoluril-Tetrathiafulvalene Molecular Clips as Receptors for Neutral Electron Acceptor Guests
}

\author{
Yoann Cotelle, Magali Allain, Stéphanie Legoupy, and Piétrick Hudhomme* \\ Université d'Angers, Laboratoire MOLTECH-Anjou, CNRS UMR 6200, 2 Boulevard Lavoisier, F-49045 Angers, France
}

Supporting Information

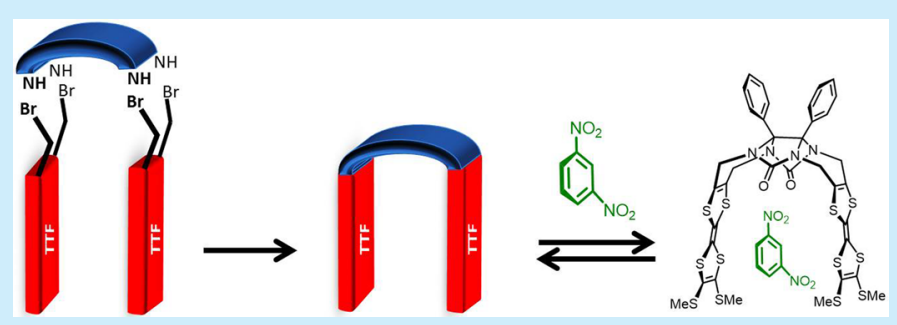

ABSTRACT: Glycoluril-based molecular clips incorporating tetrathiafulvalene (TTF) sidewalls have been synthesized, and the efficient binding ability in solution of this host architecture toward $m$-dinitrobenzene through donor-acceptor interaction has been demonstrated.

$\mathrm{T}$ he recognition of neutral guests still remains one of the main challenges in the field of supramolecular chemistry, and molecular clips have been recently investigated to address this particular issue. ${ }^{1}$ These molecular receptors are constituted by an open cavity defined by a central platform connected to two arms chosen for their capability to sandwich molecular guests through weak interactions. The glycoluril scaffold ${ }^{2}$ has become a highly efficient preorganized and rigid spacer which has been largely used in the preparation of host molecular systems such as molecular clips, ${ }^{3}$ but also capsules ${ }^{4}$ and cucurbit $[n]$ uril macrocycles. ${ }^{5}$ Nevertheless, glycoluril-based molecular clips bearing electroactive sidewalls and capable of binding guests through donor-acceptor interactions have been poorly investigated. We describe here the synthesis, X-ray crystal structures, and binding properties of glycoluril-derived molecular clips 1-3 incorporating electron-rich tetrathiafulvalene (TTF) sidewalls (Figure 1). Only a few TTF-containing molecular clips based on a rigidified calix-[4]pyrrole, ${ }^{6}$ calix[2] pyrrole[2] thiophene, ${ }^{7}$ calix-[4] arene $^{8}$ platform or a more

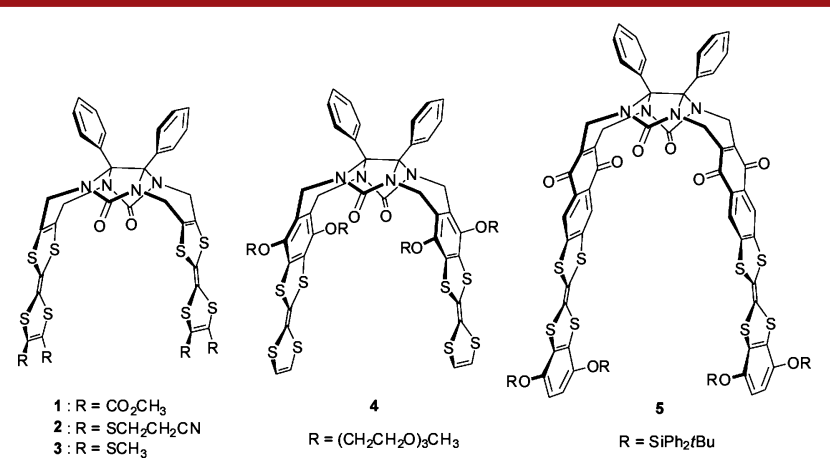

Figure 1. Formula of glycoluril-TTF molecular clips. flexible benzo[ $\left[1,2-f: 4,5-f^{\prime}\right]$ bis $[1,4]$ dithiocine spacer ${ }^{9}$ have been reported so far in studying the host-guest binding of electrondeficient guests. Using the glycoluril scaffold, hydroquinone derivative $^{10}$ or naphthoquinone ${ }^{11}$ spacers were introduced to position both TTF units at the suitable interplanar distance for complexation of the paraquat or $\mathrm{F}_{4}$-TCNQ guest molecule inside the cavity, respectively. These corresponding molecular clips 4 and $\mathbf{5}$ were synthesized through a five- and four-step synthetic strategy, respectively, starting from diphenylglycoluril 6.

Here we design a new type of electron-rich clip-shape host molecules based on the glycoluril platform on which TTF arms are directly connected without any spacer. The synthetic strategy of these molecular clips $\mathbf{1 - 3}$ is based on a straightforward nucleophilic substitution from diphenylglycoluril 6 leading to a seven-membered ring (Scheme 1). Starting material 6 was prepared in $80 \%$ yield according to literature using commercial and cheap benzyl and urea materials. ${ }^{12}$ Considering that urea $\mathrm{N}$-alkylation of compound 6 has been successfully developed with the 2,3-bis(bromomethyl)benzene derivative in a basic medium in DMSO, ${ }^{13}$ we first applied this methodology using 4,5-bis(bromomethyl)-2-thioxo-1,3-dithiole $7 .^{14}$ The reaction carried out in the presence of $t \mathrm{BuOK}$ in DMSO by controlling the temperature at $20{ }^{\circ} \mathrm{C}$ afforded compound 8 in $36 \%$ yield. Trimethylphosphite mediated crosscoupling using 2-oxo-1,3-dithiole moiety $9 a^{15}$ or $9 b^{16}$ gave corresponding molecular clip 1 or 2, respectively, in $15 \%$ yield. For compound 2, we could explain this low yield by the presence of byproducts, such as phosphonate derivatives $\mathbf{1 0}$ and 11 which were characterized in the crude reaction mixture by ${ }^{1} \mathrm{H} \mathrm{NMR}$, thanks to the coupling constants $\left({ }^{2} J_{\mathrm{H}-\mathrm{P}}=5.6 \mathrm{~Hz}\right.$ and

Received: February 12, 2014

Published: April 24, 2014 
Scheme 1. Synthesis of Glycoluril and TTF-Based Molecular Clips

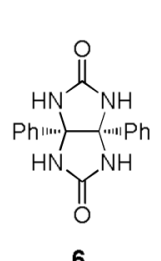

6

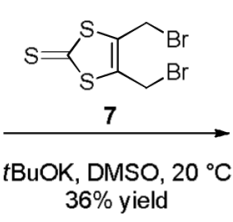<smiles>O=C1N2Cc3sc(=S)sc3CN3C(=O)N4Cc5sc(=S)sc5CN1[C@]2(P)[C@]34[PH3+]</smiles>

8
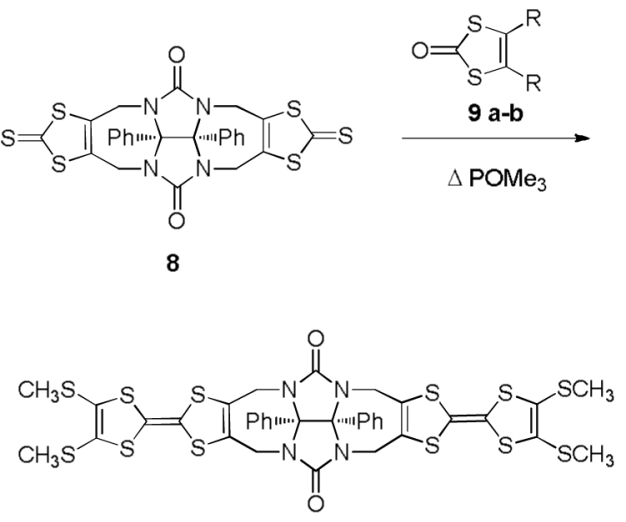

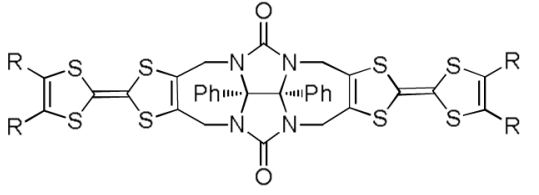

$1: \mathrm{R}=\mathrm{CO}_{2} \mathrm{Me}, 15 \%$ yield

$2: \mathrm{R}=\mathrm{SCH}_{2} \mathrm{CH}_{2} \mathrm{CN}, 15 \%$ yield

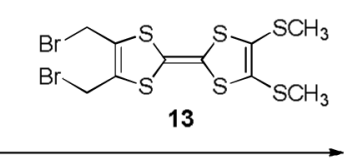

tBuOK, DMSO, $20^{\circ} \mathrm{C}$ $48 \%$ yield

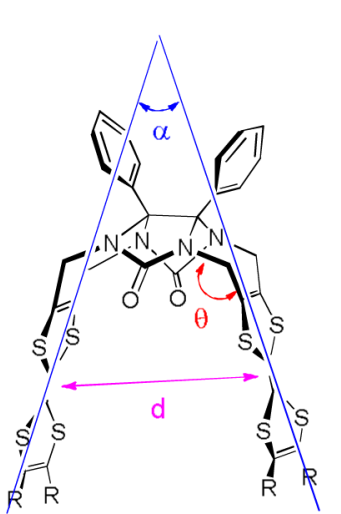

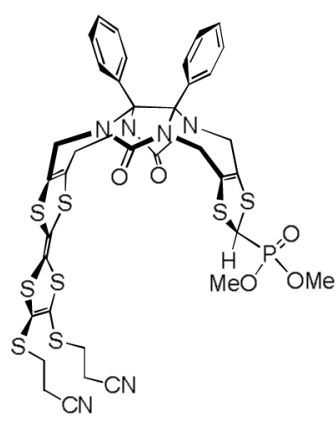

10
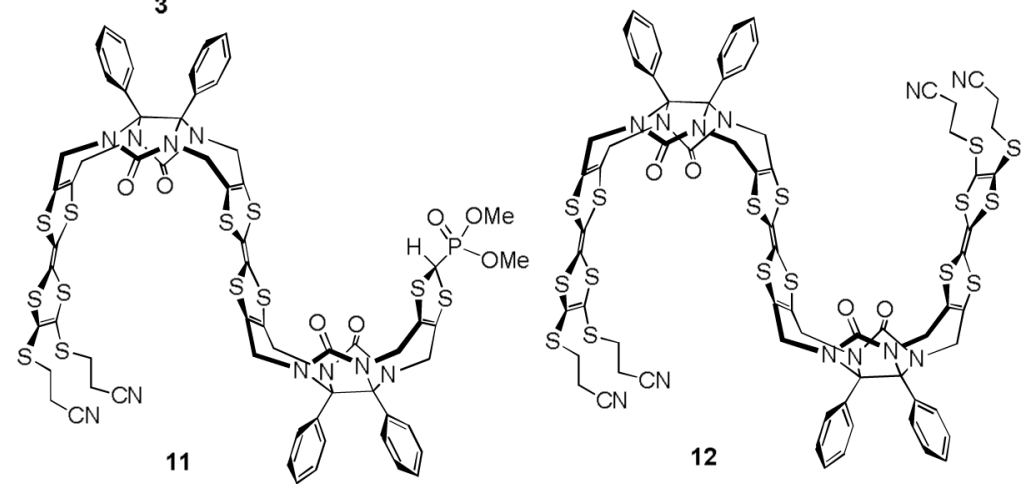

${ }^{3} J_{\mathrm{H}-\mathrm{P}}=10.7 \mathrm{~Hz}$ ) and MALDI-TOF mass spectrometry. The formation of these structures is consistent with the reaction of the thione functionality using trialkylphosphite in diluted conditions. ${ }^{15}$ The formation of compound $\mathbf{1 2}$ was also evidenced by MALDI-TOF mass spectrometry $\left(\mathrm{M}^{+\bullet}=1636\right)$, but this original bis-molecular clip has not been yet isolated. Deprotection of 2-cyanoethylsulfanyl protective groups was achieved using $\mathrm{CsOH} \cdot \mathrm{H}_{2} \mathrm{O}$ in a $\mathrm{DMF} / \mathrm{MeOH}$ mixture. ${ }^{17}$ Subsequent tetraalkylation of the tetrathiolate intermediate was carried out by addition of iodomethane affording molecular clip 3 in $72 \%$ yield. Considering that this three-step synthesis could afford target 3 in an overall low yield, we turned our attention to a straightforward strategy using the one-step reaction between diphenylglycoluril $\mathbf{6}$ and 2,3-bis (bromomethyl)TTF 13. Such a TTF derivative, developed in our group ${ }^{18}$ has been successfully used as an efficient building block $^{19}$ to generate the corresponding diene through reductive elimination allowing Diels-Alder cycloaddition, ${ }^{20}$ or to access phosphonate for Horner-Wadsworth-Emmons olefination. ${ }^{21}$ To our knowledge, it has been involved as an electrophilic substrate in only two other examples using either potassium thiocyanate $^{22}$ or 4 -aminoTEMPO ${ }^{23}$ as the nucleophile. Here this methodology proved to be particularly efficient and the reaction between compounds 6 and 13 in the presence of $t \mathrm{BuOK}$ in DMSO at $20^{\circ} \mathrm{C}$ gave molecular clip 3 in $48 \%$ yield.

Single crystals of clips 2 and 3 were obtained by slow evaporation from $\mathrm{CH}_{2} \mathrm{Cl}_{2} /$ hexane solutions. These molecular clips crystallize in the $P \overline{1}$ triclinic group with one $\mathrm{CH}_{2} \mathrm{Cl}_{2}$ molecule included inside the cavity (Figure 2). The U-shaped conformation of these molecular clips is confirmed by the angle $\theta$ around $113^{\circ}$ defined with three $\mathrm{N}-\mathrm{C}-\mathrm{C}$ consecutive atoms of the seven-membered ring.

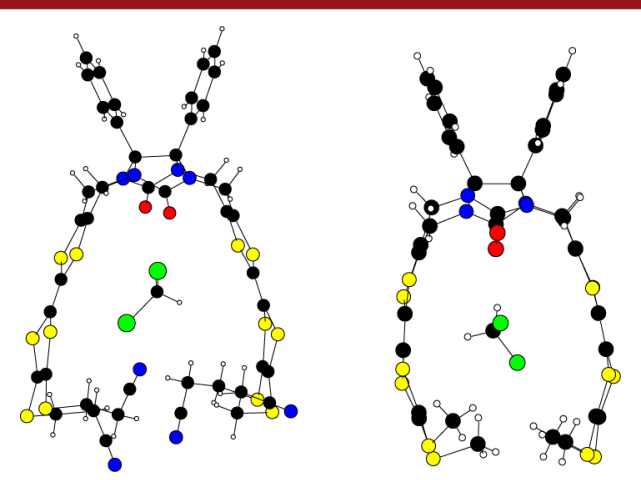

Figure 2. X-ray crystallographic structures of molecular clips 2 (left) and 3 (right).

The resulting tapering cavity could be characterized by the angle $\alpha$ taking into account both TTF moieties to define the two mean planes (Figure 2). Corresponding angles close to $43^{\circ}$ and $30^{\circ}$ for clips 2 and 3, respectively, were determined. Due to the presence of bulky terminal 2-cyanoethylsulfanyl groups, the cavity appears significantly larger in clip 2 . The distance $(d)$ between both TTF central double bonds was estimated to be equal to $8.25 \AA$ for clip 2 and must be compared with that of 7.41 A for clip 3. The three-dimensional packing in the crystal of molecular clips 2 and 3 reveals a head-to-tail arrangement between two neighboring clip molecules. It should be noted that no dimeric packing motif resulting from self-association of molecular clips with the reciprocal insertion of the TTF sidewall of one clip into the cleft of the opposing clip was observed. ${ }^{13 \mathrm{~d}, 24}$ Concerning the crystallographic packing, short interplanar distances $(3.51 \AA)$ were determined between two independent TTF molecules of clip 2 with clear evidence of 
intermolecular interactions. On the contrary, two neighboring molecules of clip 3 appeared to be significantly shifted one to each other (Supporting Information).

The cyclic voltammogram (CV) of clips 1-3 showed reversible oxidation processes corresponding to the successive generation of the cation radical and dication of the TTF moiety (Figure 3). As expected, the variation of oxidation potential

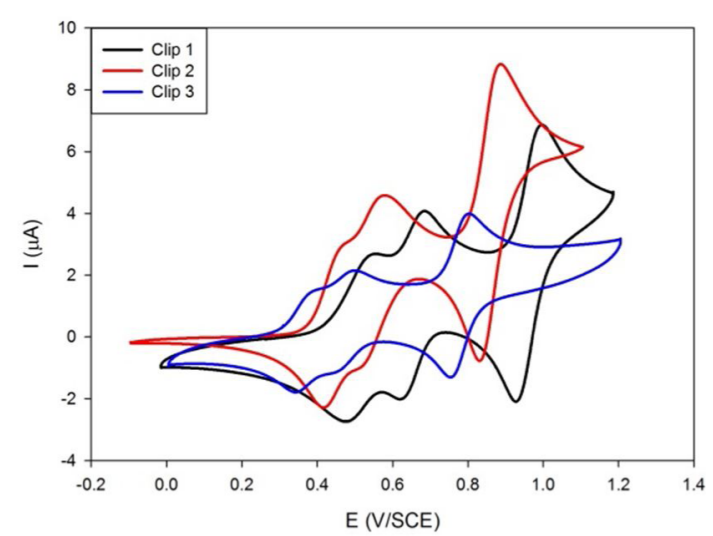

Figure 3. Cyclic voltammograms of molecular clips 1 (dark), 2 (red), and 3 (blue) in $\mathrm{CH}_{2} \mathrm{Cl}_{2} / \mathrm{CH}_{3} \mathrm{CN}$ 3:1 recorded in $n-\mathrm{Bu}_{4} \mathrm{NPF}_{6} 0.1 \mathrm{M}$ solution as the supporting electrolyte, with platinum wires as counter and working electrodes.

values is in agreement with the presence of either electrondonating $(\mathrm{SMe})$ or -withdrawing groups $\left(\mathrm{CO}_{2} \mathrm{Me}\right)$ (Table 1$)$.

Table 1. Oxidation Potentials from Cyclic Voltammograms of Molecular Clips 1, 2, and 3 (Scan Rate: $100 \mathrm{mV} / \mathrm{s}$; V vs SCE)

$\begin{array}{cccc}\text { compd } & E_{\text {ox1 }}^{\circ} & E_{\text {ox1 }}^{\circ} & E_{\text {ox2 }}^{\circ} \\ 1 & +0.50^{a} & +0.65^{a} & +0.96^{b} \\ 2 & +0.44^{a} & +0.55^{a} & +0.85^{b} \\ 3 & +0.36^{a} & +0.48^{a} & +0.77^{b}\end{array}$

${ }^{a}$ One-electron oxidation process. ${ }^{b}$ Two-electrons oxidation process.

Noticeably, the first oxidation step was split for all clips 1-3 $\left(E_{\text {ox } 1}^{\circ}\right.$ and $\left.\mathrm{E}^{\circ}{ }_{\text {ox1 }}^{\prime}\right)$. This phenomenon is characteristic of a molecular system in which two inter-TTF units interact here through space at the oxidized $\mathrm{TTF}^{+\bullet}$ state, with the Coulombic repulsion between positively charged species leading to a separation of the oxidation potentials of neutral and oxidized species. The reversible two-electrons process for the second oxidation wave $\left(E^{\circ}{ }_{\text {ox2 }}\right)$ is in accordance with independent $\mathrm{TTF}^{2+}$ units subject to repulsive electrostatic interactions.

Considering that molecular clip 3 presents the most efficient $\pi$-donating properties according to $\mathrm{CV}$ analysis and an interesting $7.41 \AA$ interplanar TTF distance, its binding ability was evaluated toward 1,3-dinitrobenzene ( $m$-DNB) which was used as a neutral electron acceptor. Whereas no modification of the ${ }^{1} \mathrm{H}$ NMR spectrum was noted upon addition of $m$-DNB into a solution of molecular clip 3 in $\mathrm{CDCl}_{3}$, the host-guest affinity was detected by UV-vis spectroscopy by monitoring the changes at $800 \mathrm{~nm}$ upon titration of clip 3 with the addition of $m$-DNB aliquots (Figure 4). A saturation was observed after the addition of approximatively 1 equiv of $m$-DNB which fits well to a 1:1 binding isotherm. A Job plot carried out in $o$ $\mathrm{C}_{6} \mathrm{H}_{4} \mathrm{Cl}_{2}$ between clip 3 and $m$-DNB exhibited a maximum at 0.5 , a finding that is consistent with the formation of the

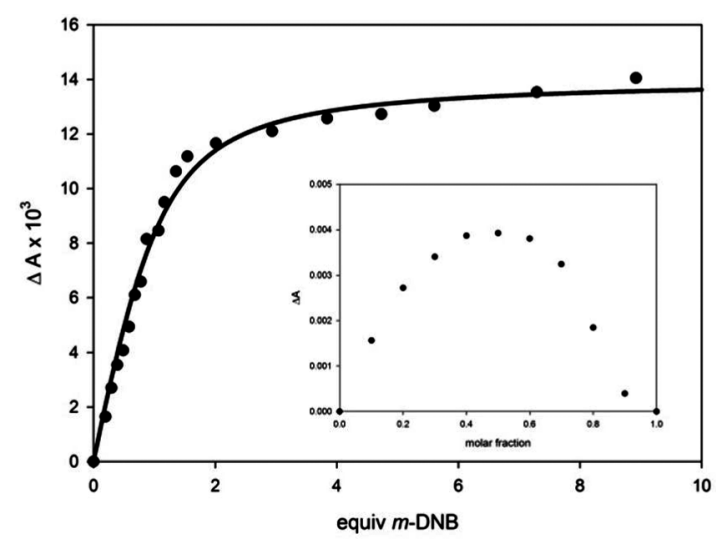

Figure 4. Plots of absorbance at $800 \mathrm{~nm}$ for molecular clip $3\left(10^{-3} \mathrm{M}\right.$ in $\left.o-\mathrm{C}_{6} \mathrm{H}_{4} \mathrm{Cl}_{2}\right)$ upon addition of $m$-DNB $\left(10^{-1} \mathrm{M}\right.$ in $\left.o-\mathrm{C}_{6} \mathrm{H}_{4} \mathrm{Cl}_{2}\right)$. Inset: Job's plot analyses at $800 \mathrm{~nm}$ confirming the 1:1 stoichiometry.

complex m-DNB@clip 3. From these results, the association constant was determined to be $K_{\mathrm{a}}=3630( \pm 540) \mathrm{M}^{-1}$. This binding value confirms that molecular clip 3 is an efficient receptor for neutral molecules, even for a weak acceptor such as $m$-DNB. This value has to be compared with the association constant $K_{\mathrm{a}}=115( \pm 10) \mathrm{M}^{-1}$ determined using UV titration by Nolte et al. for the interaction between $m$-DNB and a glycoluril based receptor incorporating 2,7-dimethoxynaphthalene sidewalls. $^{3 a, c}$

In conclusion, we have presented a straightforward synthesis of molecular clips built around the preorganized glycoluril scaffold which connects electroactive TTF sidewalls. In particular, the preparation of molecular clip 3 constitutes the first example of a one-step synthesis of a glycoluril and TTFbased host-guest architecture. The good binding ability of this system for $m$-DNB in solution is demonstrated by UV-visible spectroscopy. Moreover, the suitable interplanar distance of around 7-8 Å between TTF arms offers a great opportunity for studying the supramolecular recognition and binding association of a wide variety of neutral electron-deficient molecules involving donor-acceptor interaction.

\section{ASSOCIATED CONTENT}

Supporting Information

Experimental details, characterization data for new compounds. This material is available free of charge via the Internet at http://pubs.acs.org.

\section{AUTHOR INFORMATION}

\section{Corresponding Author}

*E-mail: pietrick.hudhomme@univ-angers.fr.

Notes

The authors declare no competing financial interest.

\section{ACKNOWLEDGMENTS}

This work was supported by a grant from the MENRT for Y.C. We gratefully acknowledge Dr. Ingrid Freuze (platform PIAM, University of Angers) for her assistance in mass spectrometry experiments.

\section{REFERENCES}

(1) For recent reviews on this topic, see: (a) Hardouin-Lerouge, M.; Hudhomme, P.; Sallé, M. Chem. Soc. Rev. 2011, 40, 30-43. 
(b) Leblond, J.; Petitjean, A. Chem. Phys. Chem. 2011, 12, 1043-1051.

(c) Pérez, E. M.; Martín, N. Chem. Soc. Rev. 2008, 37, 1512-1519.

(d) Pérez, E. M.; Illescas, B. M.; Herranz, M. A.; Martín, N. New J. Chem. 2009, 33, 228-234.

(2) Rowan, A. E.; Elemans, J. A. A. W.; Nolte, R. J. M. Acc. Chem. Res. 1999, 32, 995-1006.

(3) (a) Sijbesma, R. P.; Wijmenga, S. S.; Nolte, R. J. M. J. Am. Chem. Soc. 1992, 114, 9807-9813. (b) Sijbesma, R. P.; Kentgens, A. P. M.; Lutz, E. T. G.; Van der Maas, J. H.; Nolte, R. J. M. J. Am. Chem. Soc. 1993, 115, 8999-9005. (c) Sijbesma, R. P.; Nolte, R. J. M. Top. Curr. Chem. 1995, 175, 25-56.

(4) Rebek, J., Jr. Angew. Chem., Int. Ed. 2005, 44, 2068-2078.

(5) (a) Lee, J. W.; Samal, S.; Selvapalam, N.; Kim, H.-J.; Kim, K. Acc. Chem. Res. 2003, 36, 621-630. (b) Lagona, J.; Mukhopadhyay, P.; Chakrabarti, S.; Isaacs, L. Angew. Chem., Int. Ed. 2005, 44, 4844-4870.

(6) (a) Nielsen, K. A.; Cho, W.-S.; Jeppesen, J. O.; Lynch, V. M.; Becher, J.; Sessler, J. L. J. Am. Chem. Soc. 2004, 126, 16296-16297. (b) Nielsen, K. A.; Cho, W.-S.; Sarova, G. H.; Petersen, B. M.; Bond, A. D.; Becher, J.; Jensen, F.; Guldi, D. M.; Sessler, J. L.; Jeppesen, J. O. Angew. Chem., Int. Ed. 2006, 45, 6848-6853. (c) Nielsen, K. A.; Sarova, G. H.; Martín-Gomis, L.; Fernández-Lázaro, F.; Stein, P. C.; Sanguinet, L.; Levillain, E.; Sessler, J. L.; Guldi, D. M.; Sastre-Santos, A.; Jeppesen, J. O. J. Am. Chem. Soc. 2008, 130, 460-462. (d) Nielsen, K. A.; Martín-Gomis, L.; Sarova, G. H.; Sanguinet, L.; Gross, D. E.; Fernández-Lázaro, F.; Stein, P. C.; Levillain, E.; Sessler, J. L.; Guldi, D. M.; Sastre-Santos, A.; Jeppesen, J. O. Tetrahedron 2008, 64, 84498463. (e) Kim, D.-S.; Lynch, V. M.; Nielsen, K. A.; Johnsen, C.; Jeppesen, J. O.; Sessler, J. L. Anal. Bioanal. Chem. 2009, 395, 393-400. (7) Poulsen, T.; Nielsen, K. A.; Bond, A. D.; Jeppesen, J. O. Org. Lett. 2007, 9, 5485-5488.

(8) Düker, M. H.; Schäfer, H.; Zeller, M.; Azov, V. A. J. Org. Chem. 2013, 78, 4905-4912.

(9) (a) Azov, V. A.; Gómez, R.; Stelten, J. Tetrahedron 2008, 64, 1909-1917. (b) Skibiński, M.; Gómez, R.; Lork, E.; Azov, V. A. Tetrahedron 2009, 65, 10348-10354.

(10) (a) Chen, P.-N.; Chiang, P.-T.; Chiu, S.-H. Chem. Commun. 2005, 1285-1287. (b) Chiang, P.-T.; Chen, P.-N.; Lin, C.-F.; Liu, Y.H.; Lai, C.-C.; Peng, S.-M.; Chiu, S.-H. Chem.-Eur. J. 2006, 12, 865876.

(11) The synthesis of compound $\mathbf{5}$ will be described elsewhere in an extended work describing the influence of the spacer between glycoluril and TTF moieties on the recognition ability of these different clips towards neutral molecules.

(12) Butler, A. R.; Leitch, E. J. Chem. Soc., Perkin Trans. 2 1980, 103105.

(13) (a) Creaven, B. S.; Gallagher, J. F.; McDonagh, J. P.; McGinley, J.; Murray, B. A.; Whelan, G. S. Tetrahedron 2004, 60, 137-143.

(b) Kang, J.; Jo, J.; In, S. Tetrahedron Lett. 2004, 45, 5225-5228.

(c) Rahimizadeh, M.; Seresht, E. R.; Bakavoli, M.; Pordel, M. Can. J. Chem. 2007, 85, 964-968. (d) She, N.; Gao, M.; Cao, L.; Wu, A.; Isaacs, L. Org. Lett. 2009, 11, 2603-2606. (e) Rezaei-Seresht, E.; Hokmabadi, F. Tetrahedron Lett. 2010, 51, 2473-2476. (f) Bogaschenko, T. Y.; Lyapunov, A. Y.; Kikot', L. S.; Mazepa, A. V.; Botoshansky, M. M.; Fonari, M. S.; Kirichenko, T. I. Tetrahedron 2012, 68, 47574764.

(14) Hudhomme, P.; Le Moustarder, S.; Durand, C.; Gallego-Planas, N.; Mercier, N.; Blanchard, P.; Levillain, E.; Allain, M.; Gorgues, A.; Riou, A. Chem.-Eur. J. 2001, 7, 5070-5083.

(15) Parg, R. P.; Kilburn, J. D.; Petty, M. C.; Pearson, C.; Ryan, T. G. Synthesis 1994, 613-618.

(16) Svenstrup, N.; Rasmussen, K. M.; Hansen, T. K.; Becher, J. Synthesis 1994, 809-812.

(17) Simonsen, K. B.; Becher, J. Synlett 1997, 1211-1220.

(18) Hudhomme, P.; Liu, S.-G.; Kreher, D.; Cariou, M.; Gorgues, A. Tetrahedron Lett. 1999, 40, 2927-2930.

(19) Gorgues, A.; Hudhomme, P.; Sallé, M. Chem. Rev. 2004, 104, $5151-5184$.

(20) Hudhomme, P. C. R. Chimie 2006, 9, 881-891.
(21) (a) Gautier, N.; Samuel, R.; Sahin, Y.; Levillain, E.; Leroy-Lhez, S.; Hudhomme, P. Org. Lett. 2004, 6, 1569-1572. (b) Hudhomme, P.; Sallé, M.; Gautier, N.; Belyasmine, A.; Gorgues, A. ARKIVOC 2006, 4, $49-72$.

(22) Jeppesen, J. O.; Takimiya, K.; Thorup, N.; Becher, J. Synthesis 1999, 5, 803-810.

(23) Fujiwara, H.; Ojima, E.; Kobayashi, H. Synth. Met. 2001, 120, 971-972.

(24) Wang, Z.-G.; Zhou, B.-Z.; Chen, Y.-F.; Yin, G.-D.; Li, Y.-T; Wu, A.-X.; Isaacs, L. J. Org. Chem. 2006, 71, 4502-4508. 